\title{
Cancer Institute withholds grant
}

\section{Straus denies fresh charges of impropriety}

\section{Washington}

The running battle between the US National Cancer Institute (NCI) and research scientist Dr Mark Straus of the New York Medical College (NYMC) in Valhalla, New York State, entered a new round last week when the institute announced it was suspending part of Dr Straus's current grant because of failure to comply with federal rules on the use of human subjects in research.

Dr Vincent DeVita, the director of NCI, has also informed the medical college that the final part of the three-year, $\$ 910,000$ grant is being withheld from the beginning of March on the basis of a site-visit team's report that there has been "minimal progress" in the research into the application of cell kinetics to chemotherapy.

Dr Straus has angrily denied both the charges. On the first, he argues that his work with human cancer patients has involved only conventional radiotherapy and chemotherapy, and is therefore not covered by federal research rules. On the second, he argues that the conclusions of the visiting team are at variance with reports prepared by three previous visiting teams which each claimed that progress in the research was satisfactory.

Four years ago, Dr Straus was relieved of his position as chief of the oncology department at Boston University after the discovery that patients' records had been falsified in part of a broad survey of cancer treatment, supported by NCI, for which he had been the principal investigator.

Dr Straus, who has denied allegations that he was responsible for the forged data, has since moved to NYMC where he is professor of medicine and chief of the department of oncology. In 1979 he was awarded a three-year grant, beginning in March 1980 , to continue his research into cell kinetics following what Dr DeVita has described as a "very good"' score by scientific reviewers of his grant application.

Disagreements between Dr Straus and $\mathrm{NCI}$ emerged last summer, when NCI was accused by members of the Senate's Labor and Human Resources Committee of failing to take stricter action against him in the light of the Boston allegations. Several senators were especially critical of the fact that Dr Straus had been awarded a new $\mathrm{NCI}$ grant even though his previous activities were under investigation.

Dr DeVita defended the grant on the basis of the high marks it had received from reviewers but said that support for the clinical trials proposed in the application

had not been provided. After the Senate hearing, at which he received some harsh criticism from the committee's chairman, Senator Orrin Hatch of Utah, Dr DeVita received a strong public vote of confidence from the cancer research community.

The new disagreement between NCI and Dr Straus seems to focus on his treatment of cancer patients with a combination of radiation and the drug 5-fluorouracil (5-FU), which was approved by the Food and Drug Agency as an anti-cancer agent several years ago and is widely used by physicians and clinical oncologists.

$\mathrm{NCI}$ contends that even though it was not part of the NCI grant, Dr Straus's use of such treatment was experimental, and that a research protocol should therefore have been submitted to the medical college's institutional review board under

\section{Amersham International floats}

Amersham International, the supplier of radioactive chemicals being sold off this week by the British government, seems likely to cause a minor sensation on the London Stock Exchange. On Monday this week, the financial community was persuaded that the 50 million shares could have been successfully offered for sale at a higher price than $£ 1.42$ each, thus recouping a larger sum for British taxpayers and providing the company with a larger stock of working capital than the $£ 5$ million it now expects. As things are, the offer for sale was expected to be heavily oversubscribed.

The sale of Amersham has been on the cards for the past two years, and is broadly welcomed by the management of the company. Arrangements have been made to give each employee $£ 50$ worth of shares, and there are also arrangements whereby employees may buy further shares, now and in the future, which will be held in trust for them.

The argument that Amersham is being sold too cheaply derives from the company's rapid growth in recent years and from the relatively high profit ( $£ 8.0$ million) before tax forecast for the current year. But some in the financial community point out that the offer price is 18.9 times the expected profit after tax, a largeish ratio for conventional businesses but by no means as great as the price of shares in other high-technology companies, electronics for example.

In such circumstances, shares are preferably sold by tender, with the highest bidders being given preference. On this occasion, however, the merchant banks handling the sale of shares appear to have persuaded the British Treasury that a sale by tender would have been too complicated for many would-be investors.

The Treasury seems also to have devised new federal regulations.

Since this was not done, Dr DeVita said in a letter last month to NYMC president Dr John Connolly, the result has been a "material failure to comply with the terms of the grant". The clinical portion of the grant has therefore been suspended "until the matter is resolved to NCI's satisfaction or until the grant is terminated", as required by federal regulations.

Asked to explain how funding for the "clinical portions" of the grant could be suspended if Dr DeVita had previously assured the Senate committee that no clinical work was covered by the grant, $\mathrm{NIH}$ officials admitted last week that this had caused some unfortunate confusion. "The statement made last summer should have said that the approved grant did not involve therapeutic research, rather than

an ingenious device for assuring the future independence of the company. The government will retain a single "special rights preference share" that will allow it to prevent either a substantial disposal of the assets of the company or a significant change in the pattern of share ownership that might compromise independence.

That Amersham is attractive to investors at this point in its history is easily understood. The company's new plant at Cardiff has come into production within the past year, while the weakening of sterling in relation to the dollar within the past year has necessarily increased the profits of the company, which earns 80 per cent of its revenue outside the United Kingdom. (The prospectus estimates that a five per cent change in the value of sterling implies a ten per cent change in profit.)

Amersham's interest in genetic manipulation through its sale of labelled nucleotides and other materials used in genetic manipulation, at least at the research bench, seems not to have been widely appreciated by the financial press, which may moderate the embarrassment caused to the company's merchant banks by an even more heavily oversubscribed offer than that now in prospect.

The prospectus for the public sale of shares explains that Amersham International owes its existence to a business established in 1940 to refine radium used in the manufacture of self-luminous components for navigational aids. The company employs just over 2,000 people, three-quarters of them in the United Kingdom and most of the remainder in North America and West Germany. In recent years, Amersham has been spending seven per cent of its revenue on research and development. The City of London is impressed; others wonder whether it is enough. 